\title{
A Study Conception about Language Similarities
}

\author{
Joel Laffita Rivera \\ Faculty of Applied Communication (FAC), Multimedia University, Selangor, Malaysia \\ Email: Joel.laffita@mmu.edu.my
}

How to cite this paper: Rivera, J. L. (2019). A Study Conception about Language Similarities. Open Journal of Modern Linguistics, 9, 47-58.

https://doi.org/10.4236/ojml.2019.92005

Received: February 7, 2019

Accepted: March 12, 2019

Published: March 15, 2019

Copyright $\odot 2019$ by author(s) and Scientific Research Publishing Inc. This work is licensed under the Creative Commons Attribution International License (CC BY 4.0).

http://creativecommons.org/licenses/by/4.0/

\begin{abstract}
The present study contains a suitable literature material about linguistic similarities between English and Spanish languages. The linguistic components chosen from both languages to conduct the study research are as follows: 1) Pronunciation. 2) Vocabulary. 3) Grammar. The study contextualizes throughout its collected works data based on alphabetical-phonology, wordlist-cognates, adjectives-adverbs-verbs-patterns as well as an oriented-methodology. At present, there is a need to continue making available methodology-inputs and learning materials to support the acquisition of Spanish as Second Foreign Language (ELE). Therefore, the research article aimed to provide a manuscript through which Spanish/English bilingual Spanish language teachers and English speaking learners of Spanish know about language analogies and the advantages of doing so to enhance and empower cognitive domains and language competences regarding to the target language.
\end{abstract}

\section{Keywords}

Phonetic, Orthography, Transcription, Lexicon, Syntax, Grammatical-Structures, Teaching, Learning

\section{Introduction}

English and Spanish, these two European languages which originated from the Latin, have many things in common to share when it comes to similarities. Even though the two languages have developed their own well-designed linguistic characteristics during the course of the time; the fact is that the likenesses between the two languages can be found in the three main pillars of both languages' structure. There are many similarities between English and Spanish; both languages use the Roman alphabet and that knowledge helps build a phonemic 
and phonological foundation ${ }^{1}$ (August, Calderón, \& Carlo, 2002). Thus, consonants with similar and identical pronunciation make up the structure of the alphabet of these two languages facilitating that way the foundation mentioned. For instance, the sound of the alphabet letters (M/N/L/S/F). Regarding vocabulary such as the cognates, words similar in spelling and meaning, the existence of a gran number of these kinds of words in both languages is astonishing. In this aspect the examples are multiples in similarity and identical spelling-in some cases (education/educación/prfessor/professor/idea/idea). According to the opinion of some scholars; one key to expanding Spanish vocabulary quickly, especially as beginners, is learning to recognize the word patterns seen in many English-Spanish "cognates"2 (Erichsen, 2015). Referring to grammar such as adjectives, adverbs and verbs; the similarities found between the two languages is quite significant and the examples to cite are various and in a wide range (responsible/responsable/intelligently/inteligente/to educate/educar ext. The following headings and sub-headings present the finding of this research article paper.

\section{Alphabet Letters-Analogue Designs}

The modern English alphabet is a Latin alphabet consisting of 26 letters (each having an uppercase and a lowercase form)-exactly the same letters that are found in the ISO basic Latin alphabet. This short statement matches the view of other researches when it comes to identify origin ${ }^{3}$ (Rosen, 2015). As Spanish is also a language derived from the Lain, it should not be a surprise that the one who knows the letters of the English alphabet will be able to recognize the letters of the Spanish alphabet too. This referent will provide the first insight of what we call "phonetic". Learning the Spanish alphabet requires only learning three more letter than are found in the English alphabet. These include ch (che), ll (elle) and ň (eňe), they fit into the alphabet in an order that also makes sense, following the letter from the English alphabet that starts with the same similar letter $^{4}$ (Blackburn, 2015). If well is true that there are some differences in a few cases, this cited point can be better understood by simply illustrating the two languages alphabet letters configuration:

\section{English Alphabet Letters}

\section{A B CDEF GHIJKL MNO PQRSTUVWXZ \\ Spanish Alphabet Letters \\ A B C CH D E F G H I J KL LL MNÑ OPQRSTUVWXZ}

Seen from a chronological perspective the two languages' alphabet structures are identical, just the Spanish alphabet letters mentioned in the previously article statement differentiate this arrangement. Even though the pronunciation of Spanish alphabet letters could be perceived difficult to pick up for English lan-

${ }^{1}$ August, D., Calderón M., \& Carlo M. (2002). The Transfer of Skills from Spanish to English: A Study of Young Learners. Center for Applied Linguistics, Washington, D.C.

${ }^{2}$ Gerald Erichsen (2015). Grammatical Differences between Spanish and English.

${ }^{3}$ Michael Rosen (2015). Alphabetical: How Every Letter Tells a Story.

${ }^{4}$ Jerry K. Blackburn (2015). An Easy Comparison of the English to Spanish Alphabet. 
guage's speaker learners the most accuracy way to access these learners according to this language issue is by providing a converted spelling pronunciation transcript, especially when working with adult learners:

\section{Ex. From Spanish to English: B/ b/(standard) -(practical) B/bay/}

According to some analysis the sound of Spanish letters easy to pick up by English speakers learners of Spanish are $(\mathrm{C} / \mathrm{CH} / \mathrm{F} / \mathrm{K} / \mathrm{M} / \mathrm{P} / \mathrm{Q} / \mathrm{S} / \mathrm{T} / \mathrm{W} / \mathrm{Y})$. On the other hand, the Spanish alphabet letters which sound are difficult to pick up by the same kind of learners are $(B / D / G / H / J / L / L L / N / N / R / X / Z)$. Even though getting the right pronunciation of all Spanish alphabet letters requires multiple practical intonation tasks; thinking in mind the similarities between the two languages will help to accomplish (in part) the wanted goal.

\section{Consonant and Vowel Inputs}

Unlike English, in Spanish all alphabet letters "consonants" have distinguished orography spelling which consists in combining "consonants and vowels". So, when it comes to spell out any word or abbreviation in Spanish language this must be known:

\section{Spanish Consonants Names}

B-bel C-cel $D$-del G-gel H-hachel J-jotal $K$-kal L-ele/ LL-elle/ $M$-emel $N$-enel $\tilde{N}$-eñ el $P$-pel $Q$-cul $R$-erel $R R$-errel $S$-esel $T$-tel $V$-uvel $W$-doble uvel $X$-equis/ $Y$-ye or $i$ griegal $Z$-zeta

\section{Spelling Examples}

Murciélagol eme, $u$, ere, ce, i, e, ele, a, ge, o

DHL/de, hache, ele

As it can be observed from the content of the prior sub-heading; knowing the sound of Spanish consonants is not sufficient as it is necessary to get to know the sound of the five Spanish vowels and their significant role in terms of Spanish accentuation as well. From the English language perspective, the letters A, E, I, $\mathrm{O}$, and $\mathrm{U}$ are considered vowel letters, since (except when silent) they represent vowels; the remaining letters are considered consonant letters, since when not silent they generally represent consonants. However, Y commonly represents vowels as well as a consonant (e.g. "myth"), as very rarely does W (e.g. "cwm"). Conversely, U and I sometimes represent a consonant (e.g. "quiz" and "onion" respectively). $\mathrm{W}$ and $\mathrm{Y}$ are sometimes referred as semivowels by linguists ${ }^{5}$ (Celce-Murcia, Brinton, \& Goodwin, 1996). So, from phonologically perspectives and taking into consideration the parallels between the two languages alphabet letters it should not be a wonder that the vowels cited in that research article are the same as those that make up the Spanish alphabet letters as well as finding that the Spanish consonant "Y" has vowel sound too. However, the pronunciation of those five vowels in Spanish is completing different from their English equivalent. Generally this is a difficult pronunciation language task for

${ }^{5}$ Celce-Murcia, M., Brinton, D., Goodwin, J. (1996). Teaching Pronunciation: A Reference for Teachers of English to Speakers of Other Languages, Cambridge University Press. 
English language speaker's learners of Spanish language; because the phonological system of Spanish is significantly different from that of English, particularly in the aspects of vowel sounds ${ }^{6}$ (Gil, 2007). Even though this is true it will not be that difficult to access these kinds of learners in this regard if we put those vowels into a practical phonetic transcript followed by a constant practice since the very beginning of the Acquisition of the L2 (Spanish language):

\section{a/ah/e/eh/i/ee/o/oh/u/ool}

Due to the implication of those vowels in the formation of diphthong and triphthongs; hiatus; the use of conjunctions; interjections; tilde; dieresis; linking; division of syllables; vocabulary and grammar patterns in Spanish; there is a need to provide a clear insight on this particular Spanish vowels accentuation in order to make understood this peculiar pronunciation practice in Spanish:

In Spanish two and three vowels come together to make a sound, this phonetic peculiarity is called diphthong and triphthongs. The diphthongs are made up by combining the strong vowels plus the weak one and obi-verse, the same thing usually happens with the formation of triphthongs and hiatus, in the case of the hiatus the weak vowel is stressed and two strong vowels make up hiatus too. Following the rule of accentuation of words in Spanish; the weak vowel will be stressed to indicate that there is no diphthong. The strong Spanish vowels are $\boldsymbol{a} / \boldsymbol{e} \boldsymbol{o}$ and the weak are $\boldsymbol{i} \mathbf{u} \boldsymbol{u}$. Unlike English, in Spanish the letter " $\boldsymbol{h}$ " is silenced, nevertheless, this does not avoid the formations of diphthongs or either hiatus. The letter " $\boldsymbol{y}$ " has the vowel sound $\boldsymbol{i}$ as in $\boldsymbol{e e}$ when it comes to the formation of triphthongs as well as when it is used at the end of a word and as a conjunction. The Spanish vowels e/o/u are also used as conjunctions in this language:

Diphthongs: agual aire/ cielo/ oigo/ ruidol

Triphthongs: Uruguayl Paraguayl apreciéis

Hiatus:vehículo/ ahíncolahogarl almohada

Y: hoyy mañana

E: Padre e hijo./ Comunicación e Ingeniería

O: Dos o tres./Cinco o seis.

U: Tú u otro alumno

As in English, the interjections in Spanish do not have a significant impact in terms of grammatical structures, in many cases they are made up of a vowel and the letter " $\boldsymbol{h}$ " in both languages, however, as the letter " $\boldsymbol{h}$ " is silenced in Spanish the pronunciation of the vowel really matters in this regard in Spanish:

$$
\begin{aligned}
& \text { ¡Ah! ¡Huy! ¡Oh! (Ache) } \\
& \text { ¡Ay! (Annoyance) } \\
& \text { ¡Ah! (Attention) } \\
& \text { ¿Eh? (question) }
\end{aligned}
$$

The use of "tilde" on any of the Spanish vowels (á/é/í/ó/ú) has significant influence when it refers to voice-articulation; the vowel that carries it indicates that the voice goes up in the syllable where that vowel is used educación/profesión/matemáticalángel. This graphical accent "tilde" is also used to differentiate

${ }^{6} \mathrm{Gil}, \mathrm{J}$. (2007). Fonética para profesores de español: de la teoría a la práctica. Madrid: Arco/Libros. 
many Spanish words with the same spelling:

Mi (possessive adjetive) mí (pronoun)./Mas (in addiction) más (conjunction)./ público (noun) publicó (verb) publico (verb) ext.

In the spoken Spanish, various words are not pronounced separated in phrase or sentence, being this one of the reasons for which the use of "linking" is a practice. This kind of connection is produced when the last consonant of the word and the initial vowel of the other one are linked in one sound, when two identical vowels are linked in one sound and when two identical consonants are linked as well. The use of this language articulation can be seen in English too:

Un ángel./Laabeja./ Ellibro./ Anangel./ Anapple.

It has been clearly stated in all prior statements how important is to know the pronunciation of the vowels in Spanish correctly. In addition to that, these topics will confirm also their significant role in terms of pronunciation in Spanish. When it comes to the division of syllables, vocabulary, and grammar in this language; think in mind that "one vowel" constitutes a syllable, and due to the silenced letter " $h$ " all vocabulary and grammar words written with that letter " $h$ " will suffer its lack of sound, which will be initially placed on the vowel that precede or follow that letter:

Syllable Division

Amorla-mor

Anala-na

Oírlo-ír

Vocabulary and Grammar Words

Hogarl ahoral holal haberl hel has/ hoyl hayl ahí

\section{Vocabulary Parallel Designs}

Vocabulary is the body of words used in a particular language. Its origin is dated back to the Mid-16 ${ }^{\text {th }}$ Century (denoting a list of words with definition or translation): from Medieval Latin vocabularies, from Latin vocabulum ${ }^{7}$ (English Oxford Living Dictionaries, 2018). Not only that this statement clearly reflects the definition of vocabulary, but also the convergence of the two languages in relation to it. Due to the influence of Latin in English and Spanish; the similarity between the two regarding vocabulary, mainly "cognates" is really impressing. According to some analysis, the Spanish we know today is older than the English we know today, 37 to 38 percent of English words were taken from Spanish. Data compiled from other research sources show that $30 \%$ to $40 \%$ of all words in English language have a related word in Spanish language. This percentage of English-Spanish cognates can be seen in words that have similar spelling and same meaning and words identical in spelling and meaning in both languages. And even though the existence of other words with similar and identical orthography characteristics but different meaning "false friends" known as such in Spanish are found as well; the reality is that about $90 \%$ of Spanish cognates have the same meaning in English:

${ }^{7}$ English Oxford Living Dictionaries (2018). 


\author{
English/Spanish \\ Idea/idea \\ Education/educación \\ Publicl público \\ societyl sociedad \\ editor/ editor \\ auditor/auditor \\ Industrialization/industrialización \\ Globalization/globalización \\ Profession/profesión \\ Notion/noción \\ Revolution/ revolución \\ Formation/formación \\ Academiclacademia \\ Cable/ cable \\ Festival/ festival \\ Portall Portal \\ Production/ producción \\ Editorial/ editorial \\ Publication/publicación \\ Hospital/ hospital \\ Hotell hotel \\ Recreation/ recreación
}

\title{
5. Grammar-Matching Designs
}

A simple statement definition of what Spanish grammar is what Spanish Institute Miguel De Cervantes (dictionary) defines it as "the Spanish grammar" (Diccionario de la lengua española, 2015). This concept really makes sense when it comes to own language peculiarities and it can be a good referent point in understanding what studies a new language really means. However, as English and Spanish share Latin roots, in terms of language patterns similarities there are aspects of grammar that have matching designs in both languages: Table 1 Grammar-Matching Designs.

The examples in the table clearly described the similarity between the two languages regarding some grammar aspects. From those examples of similarities we can provide an overview about the way they are used in Spanish. For instance, the adjectives that end in "o" are usually masculine, to get the feminine form " 0 " is substituted by " $a$ ". The adjectives that end in " $e$ " and "ista" and "al" are neuters, which mean that they do not have gender. Most of English adverbs that end in " $l y$ " have their equivalent of "mente" in Spanish.

\section{Syntax and Semantic Structure}

Although Spanish is a much more heavily inflected language than English; when

${ }^{8}$ (Diccionario de la lengua española) 23a Edición, 2015. Madrid: Espasa. ISBN: 978-84-670-4189-7. 
Table 1. Grammar-matching designs.

\begin{tabular}{ccc}
\hline Adjectives & Adverbs & Infinite Verbs Forms \\
\hline $\begin{array}{c}\text { intelligent/inteligente } \\
\text { educated/educado } \\
\text { realistic/realista }\end{array}$ & personally/personalmente & to communicate/comunicar \\
optimistic/optimista & absolutely/absolutamente & to motivate/motivar \\
pessimistic/pesimista & frequently/frecuentemente & to imagine/imaginar \\
honest/honesto & naturally/naturalmente & to educate/educar \\
responsible/responsable & completely/completamente & to permit/permitir \\
comfortable/confortable & originally/originalmente & to observe/observar \\
punctual/puntual & occasionally/ocacionalmente & to admit/admitir \\
considerable/considerable & permanently/permanentemente & to construct/construir \\
nonorable/honorable & intelligently/inteligentemente & to dedicate/dedicar \\
voluntarily/voluntariamente & to produce/producir
\end{tabular}

it comes to semantic the word order of the Spanish into sentences is similar to its English equivalent: Subject-Verb-Object (SVO). Regarding to the writing of phrases formed by an article + adjective + noun in English; the equivalent of these phrases is also quite similar when it comes to use the three syntax components required to write these kinds of phrases in both languages, which composition in Spanish is generally: article + noun + adjective. The differences to think in mind are related to the use of gender and number plus the word-order in Spanish. However, we can play with the word order to provide phrases and sentences constructions, particularly by using nouns, adjectives, verb-forms and tenses that have similar grammatical constructions in both languages:

\section{Phrases}

An intelligent profesor./ Un profesor inteligente.

An educated student./ Unestudianteeducado.

\section{Verb-Tenses}

Present Indicative/ Present Perfect/Present Progressive

\section{Examples (SVO)}

I have family./ Yo tengo familia.

I have finished the homework./ Yo he terminado la tarea.

I am studying now./ Yo estoy estudiando ahora.

As can be seen from all the writings shown in this research article; the language pattern similarities between English and Spanish can provide clear insights for the learners to acquire and to develop language functions in relation to the Second Language Acquisition (SLA). Apart from this, the subject matter is to think in mind the rules, principles, and processes that govern the structure of those skills in a given language, and by doing so learners will be able to apply those abilities in Spanish language as appropriate. 


\section{Aim of the Study}

The study aim has been to provide a script through which Spanish/English bilingual Spanish language teachers and English speaking learners of Spanish knowing about language analogies and the advantages of doing so to enhance and empower cognitive domains and language competences in relation to the target language (Spanish). The study has delivered at angible overview about linguistic patterns similarities between English and Spanish languages which can be beneficial in teaching and learning Spanish Language as Second Foreign Language (ELE).

\section{Study Oriented-Methodology}

Although there are several methods to teach and learn foreign languages, specially methods related to the language references which have been pointed out in this research article; this study has considered to provide a method which has been used in Spanish language classes conducted at Multimedia University (MMU), Malaysia with favorable results. The method provides insights on how to take advantages from pronunciation, vocabulary and grammar alignment-analogue between the two languages to setup appropriate teaching and learning assistance to English speaking learners of Spanish language as second foreign language (ELE). This method is suitable to access Spanish beginner's students (A1) according to what is prescribed by the Common European Framework of Reference for Language Learning, Teaching, Assignment $(\text { CEFR) })^{9}$ (de Europa, 2001) and the ${ }^{10}$ American Council on the Teaching of Foreign Languages (ACTFL), 2017. So, we begin with a synchronized set of tasks:

Spanish Alphabet: In Spanish the capitals letters are known as (mayúsculas) and the small letters as (minúsculas); you just need to pick up the name of any letter and spell out that given name. For example, B (mayúscula)/b (minúscula), the letters ( $\mathrm{c}$ and $\mathrm{g}$ ) have different sound which depends on the vowel that follows them. The letter " $y$ " has the vowel sound "ee" when it is used as a conjunction which means "and" and at the end of a word "hoy". Learning the "name" of the letters will help you to say how the "words and the abbreviations" are spelled in Spanish. Learning the "pronunciation of consonants and vowels and some others issues related to the diphthong and triphthongs; hiatus; the use of conjunctions; interjections; tilde; dieresis; linking; division of syllables; it will allow a better understanding and acquisition of the Spanish pronunciation accordingly. Table 2: Spanish Alphabet-Converted Spelling Pronunciation Transcript below shows the letters that makeup the Spanish alphabet together with their "reading name and example of English words to point out the way they are pronounced in most of the Spanish-speaking countries".

${ }^{9}$ Consejo de Europa (2001). Marco Común Europeo de Referencia para las Lenguas: aprendizaje, enseñanza, evaluación.

${ }^{10}$ American Council on the Teaching of Foreign Languages (2017). 
Table 2. Spanish alphabet-converted spelling pronunciation transcript.

\begin{tabular}{|c|c|c|}
\hline Letters & Letters Reading Name & Pronunciation as in the examples \\
\hline A-a & ah & $\mathbf{a} \leftrightarrow$ father \\
\hline B-b & beh & b $\leftrightarrow$ obey \\
\hline $\mathrm{C}-\mathrm{c}$ & say & ca, ce, ci, co, cu↔car, cereal/th, cinema/th, coconut, cooking \\
\hline $\mathrm{CH}-\mathrm{ch}$ & chay & ch↔church \\
\hline D-d & day & $\mathrm{d} \leftrightarrow$ diet \\
\hline E-e & ay & e $\leftrightarrow$ eight \\
\hline F-f & ef-ay & $\mathrm{f} \leftrightarrow \mathrm{fox}$ \\
\hline G-g & hay & ga, ge, gi, go, gu↔guy, help, him, go, good/gue $\leftrightarrow$ gest, gui $\leftrightarrow$ guitar/güe $\leftrightarrow$ goo-a, güi $\leftrightarrow$ goo-ee \\
\hline $\mathrm{H}-\mathrm{h}$ & ah-chay & silenced \\
\hline $\mathrm{I}-\mathrm{i}$ & ee & $\mathbf{e} \leftrightarrow \mathrm{see}$ \\
\hline$J-j$ & hotah & $\mathbf{h} \leftrightarrow$ house \\
\hline $\mathrm{K}-\mathrm{k}$ & kah & $\mathbf{k} \leftrightarrow$ karate \\
\hline L-1 & el-ay & $1 \leftrightarrow$ little \\
\hline LL-11 & ay-yay & $\mathrm{y} \leftrightarrow$ yellow \\
\hline M-m & em-ay & $\mathrm{m} \leftrightarrow$ mother \\
\hline$N-n$ & en-ay & $\mathbf{n} \leftrightarrow$ nice \\
\hline$\tilde{N}-\tilde{n}$ & en-yay & $\tilde{\mathbf{n}} \leftrightarrow$ canyon \\
\hline $\mathrm{O}-\mathrm{o}$ & oh & o↔orange \\
\hline P-p & peh & $\mathrm{p} \leftrightarrow$ spot \\
\hline Q-q & coo & $\mathbf{q} \leftrightarrow$ kilometre \\
\hline R-r & air-ay & $\mathbf{r} \leftrightarrow$ air \\
\hline RR-rr & airrr-ay & $\mathrm{rr} \leftrightarrow$ airrrinatrill \\
\hline S-s & es-ay & $\mathbf{s} \leftrightarrow$ special \\
\hline T-t & teh & $\mathbf{t} \leftrightarrow$ stop \\
\hline $\mathrm{U}-\mathrm{u}$ & oo & $\mathbf{u} \leftrightarrow$ cooking \\
\hline V-v & oo-beh & $\mathbf{v} \leftrightarrow$ beach \\
\hline $\mathrm{W}-\mathrm{w}$ & doh-bleh-oobeh & $\mathbf{w} \leftrightarrow$ whisky \\
\hline$X-\mathrm{x}$ & eh-keys & $\mathbf{x} \leftrightarrow \operatorname{taxi}$ \\
\hline Y-y & ee-gree-ay-gahoryay & $\mathrm{y} \leftrightarrow$ уоуо \\
\hline $\mathrm{Z}-\mathrm{z}$ & say-tah & $\mathbf{z} \leftrightarrow$ specialorthin \\
\hline
\end{tabular}

\section{Teaching and Learning-Practical Exercises}

Instruction: Read the Spanish alphabet. Then, read the combinations between consonants and vowels.

\section{A B C CH D E F G H I J K L LL M N Ñ O P Q R S T U V W X Z}

ce ci ca ge ga gu gi ha ho ju jo chi chu ña ñe bi be ve vi xa xe qui que gue gui güe güi 
Instruction: Provide a list of English-Spanish cognates (identical in spelling) that catch attention, engage and motivate students to practice the pronunciation in the target language. They will soon realize that is possible to be bilingual.

Ex. Ideal terrible/ cable/ hotell festivall original ext.

ABC-Words Building

Instruction: Provide a list of English-Spanish cognates that allow students to practice pronunciation; knowing about spelling rules; use of accent-tilde; and gender of nouns-notion as well as exploring \& differentiating meaning. Use the dictionary to find and evaluate/discuss the meaning of cognates in order to enhance vocabulary and grammar.

Ex: Education (educación)/angel (ángel)/terrible (terrible)/carpet (alfombra) ext.

From $\mathrm{ABC}$ to the Phrase in the Context

Instruction: Provide English/Spanish word-phrases (cognates) that allow students to practice pronunciation and knowing about word-order in Spanish.

Ex. Cultural manifestation. (Manifestación cultural)/Latin music. (Música Latina)/International festival. (Festival Internacional) ext.

Instruction: Provide English/Spanish grammar-words (cognates) that allow students knowing about grammar (adjectives/adverbs/tenses and verb-conjugations) in Spanish.

Ex. Intelligent (inteligente)./Educated (educado-a-s)./ Realist (realista)./Honestly (honestamente)./ To respond (responder) infinite./Imperative verb-forms (responde/ responda) ext.

\section{Results and Discussion}

This study has conducted close observations based on the wide percentage of linguistic pattern similarities between English language and Spanish language as shown in the literary-content of this research article. These observations were carrying out in Spanish language classes conducted at Multimedia University (MMU), Malaysia. The study of this analogue-linguistic between the two languages are influenced by factors such as knowledge and application of those linguistic patterns similarities in teaching and learning Spanish language, particularly when working with English speaking leaners of Spanish as second foreign language. Furthermore, other factors include lack of learning practical materials that direct highlight these linguistic patterns similarities. Spanish language lessons about linguistic patterns similarities that can be vital in overcoming some challenges regarding current teaching and learning methodologies for teaching and learning foreign languages. In these regards, the study has evaluated other research studies view and methodologies in order to make available a suitable manuscript. This study contains an explicit overview about linguistic pattern similarities between the two languages. The linguistic components selected to conduct and prove the accuracy of this study are accompanied by contextualized explanations to allow the comprehension of the topics exposed. Examples based 
on those topics are given. The study has provided also an oriented-method which has resulted to be efficient in developing language competences among English speaking learners of Spanish as second foreign language. The purpose of this method is to help Spanish/English bilingual Spanish language teachers and English speaking learners of Spanish getting to know how to take advantages of the similarities between the two languages to enhance and empower Spanish language competences accordingly. In general, this study intends to emphasize the significant of knowing and applying these linguistic patterns similarities in teaching and learning practices.

\section{Conclusion}

This study has outlined linguistic patterns similarities between English language and Spanish language in attempting to benefit the teaching and learning of Spanish language with English learners of ELE. The collected data of this study are accompanied by the professional view of its author as well as supported literature of others researchers. To validate the authenticity of the research article the study has displayed all over its headings and sub-headings a suitable literature material. The modest outcome of this study research is a contribution to continue searching for teaching and learning approaches that help English speaking learners of Spanish language to accomplish their language development successfully.

\section{Acknowledgements}

The author is very thankful to all the associated personnel in any reference that contributed in/for the purpose of this research.

\section{Conflicts of Interest}

The research holds no conflict of interest.

\section{Funding}

The research is not funded through any source.

\section{References}

(2015). Diccionario de la lengua española (23rd Edición). Madrid: Espasa.

(2018). English Oxford Living Dictionaries. https://en.oxforddictionaries.com/definition/vocabulary

American Council on the Teaching of Foreign Languages (2017). https://www.actfl.org/

August, D., Calderón M., \& Carlo M. (2002). The Transfer of Skills from Spanish to English: A Study of Young Learners. Washington DC: Center for Applied Linguistics.

Blackburn, J. K. (2015). An Easy Comparison of the English to Spanish Alphabet.

Celce-Murcia, M., Brinton, D., \& Goodwin, J. (1996). Teaching Pronunciation: A Reference for Teachers of English to Speakers of Other Languages. Cambridge: Cambridge University Press. 
de Europa, C. (2001). Marco Común Europeo de Referencia para las Lenguas: Aprendizaje, enseñanza, evaluación. https://www.examenglish.com/CEFR/cefr_es.php

Erichsen, G. (2015). Grammatical Differences between Spanish and English.

Gil, J. (2007). Fonética para profesores de español: de la teoría a la práctica. Madrid: Arco/Libros.

Rosen, M. (2015). Alphabetical: How Every Letter Tells a Story. Counterpoint ISBN 978-1619027022.

\section{Additional Biography}

Marcos, J. R. (2010). La “i griega” se llamará “ye”. El País.

Un solo nombre para cada letra.

(2005) Diccionario panhispánico de dudas [Real Academia Española] (1st ed.). (In Spanish)

Calderón, M., August, D., Durán, D., Madden, N., Slavin, R., \& Gil, M. (2003). Spanish to English Transitional Reading: Teacher's Manual. Baltimore, MD: The Success for All Foundation.

Batchelor, R. E., José, S., \& Ángel, M. (2010). A Reference Grammar of Spanish. Cambridge University Press.

Butt, J., \& Benjamin, C. (2011). A New Reference Grammar of Modern Spanish (5th ed.). Hodder Education.

DeBruyne, J. (1996). A Comprehensive Spanish Grammar. Wiley-Blackwell.

Roque Mateos, R. (2017). A Good Spanish Book!: Basic Spanish Course for Foreigners. University Academic Editions.

http://www.streetdirectory.com/travel_guide/14342/education/an_easy_comparison_of_t he_english_to_spanish_alphabet.html

https://www.spanishdict.com/guide/spanish-vowels

http://www.colorincolorado.org/article/capitalizing-similarities-and-differences-betweenspanish-and-english

https://www.fluentu.com/blog/spanish/similarities-between-spanish-and-english/

https://www.thoughtco.com/patterns-of-similarity-and-difference-in-spanish-and-englis h-3080279

http://esl.fis.edu/grammar/langdiff/spanish.htm 